\title{
Statistical Capacity, Human Rights and FDI in Sub-Saharan Africa Patterns of FDI Attraction in Sub-Saharan Africa
}

\author{
Alexander Kriebitz ${ }^{1} \&$ Laud Ammah $^{1}$ \\ ${ }^{1}$ Chair of Business Ethics, TUM School of Governance, Technical University of Munich, Germany \\ Correspondence: Alexander Kriebitz, Chair of Business Ethics, TUM School of Governance, Technical \\ University of Munich, Arcisstr. 21, 80333 Muenchen, Germany. E-mail: a.kriebitz@tum.de
}

Received: April 20, 2020 Accepted: May 20, 2020 Online Published: May 26, 2020

doi:10.5539/jms.v10n1p162 URL: https://doi.org/10.5539/jms.v10n1p162

\begin{abstract}
Foreign Direct Investment (FDI) is commonly perceived as one of the main drivers of technological progress and socio-economic development. At the same time, FDI is often regarded as an instrument of stabilising authoritarian regimes, which disenfranchise the rights of citizens to increase rents generated by foreign firms. Given that both views are accurate, the improvement of human rights and economic development could constitute two conflicting goals. This particularly applies to Sub-Saharan Africa, where a sizeable number of countries are mired in poverty and governed by authoritarian power structures. In evaluating the importance of these soft factors, we examine two important institutional factors of FDI attraction: We address the question of whether human rights violations deter FDI attraction and explore whether FDI depends on the amount of available socio-economic information about the country to be invested in. For the latter, we use a novel variable, namely the Statistical Capacity Figures of the World Bank, which depicts an indicator of effectiveness of the national statistical systems. In order to analyse the relationship between human rights and FDI, we run a regression model covering 41 Sub-Saharan countries covering the years from 2006 to 2015.
\end{abstract}

Keywords: investment in Sub-Saharan Africa, human rights and foreign investment, development policy, multinationals and authoritarian regimes, institutions, and economic growth.

\section{Introduction}

Economists typically regard the attraction of foreign companies as an instrument, which generates technological spillovers, raises the development level and integrates emerging markets in the global supply chain (c.f., Smith, 1997; Anyanwu \& Erhijakpor, 2004). According to current research on the economic miracles of China (Naughton \& Lardy, 1996) and Vietnam (Hoang et al., 2010), FDI was conducive for economic growth and foreign trade, while other studies highlight the importance of FDI for the reduction of absolute poverty (c.f., De Mello, 1999; Klein et al., 2001; Ogunniyi \& Igberi, 2014). The positive perception of FDI as an instrument for growth has resulted in the liberalisation of foreign trade regimes and regulatory changes in order to attract international investors (c.f., Coorey \& Vadlamnati, 2015).

At first glance, Sub-Saharan Africa is endowed with conditions favourable for trade and investment. However, despite its vast landmass, endowment with natural resources, pool of cheap labour and sheer market size, FDI remains underrepresented and oscillates between 1-2\% of the global investment stock. Considering the population size of the region, which represents $17 \%$ of the world population, which is likely to account for $40 \%$ of the global population in the future, and its abundance of natural resources ranging from coal to rare earths, the stark contrast between potential and real FDI is astounding. 


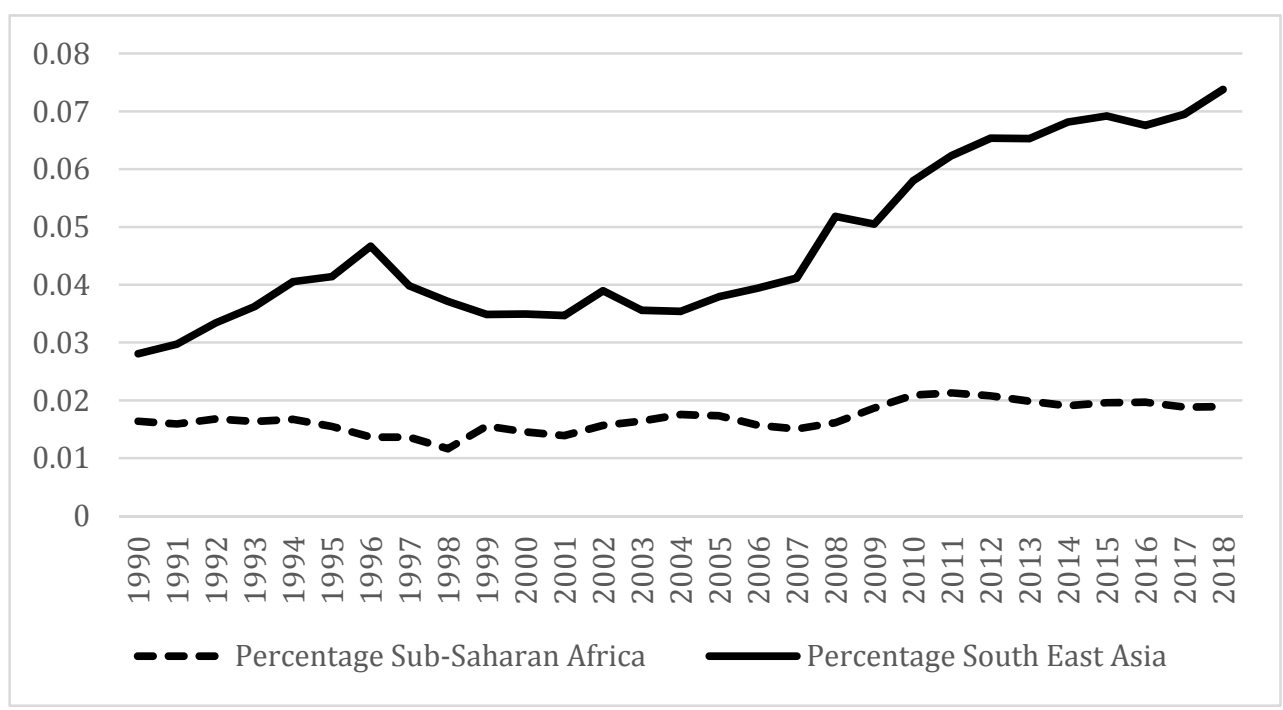

Figure 1. Distribution of FDI in Sub-Saharan Africa and South East Asia as percentage of global FDI Stock Sources: UNCTAD, 2020.

The general shift of global FDI flows from developed to developing countries notwithstanding, the gap between Sub-Saharan Africa and other regions of the Global South appears to widen (Figure 1). The reason why FDI evades Sub-Saharan Africa seems therefore to be connected to institutional and - potentially-reputational factors. To measure these aspects, focusing on human rights and the information environment concerning the country to be invested in might be very helpful, as these concepts not only capture the relevance of institutional performance, but also the moral perception of investing in repressive regimes. The latter aspect requires a short explanation. Common morality - justified or not-suggests that investment in democratic countries is more ethical than maintaining commercial ties with authoritarian regimes. This moral perspective has become influential in the debate on boycotting regimes, which are accused of breaching with normative principles such as human rights or international law (Carter et al., 2019; Kriebitz \& Max, 2020). The case of the Dutch company IHC Caland, which was criticised for its involvement in the Burmese military regime, illustrates that investing in dictatorships confronts companies with high reputational and-ultimately financial costs (de Bakker \& den Hond, 2011). Another case would be Nokia's commercial ties with the DRC and accusations of labour exploitation in Nokia's coltan supply chain (Guardian, 2016).

To disentangle the role of purely economic (hard factors), institutional and reputational (soft factors) determinants of FDI attraction, we employed a regression model, using the data of 41 countries across a period of ten years. Based on our results, we discuss the correlation and causalities between informational quality, reputation and FDI attraction detected by our statistical analysis. We found that the results represented here might be used to tailor region-specific development strategies, as they highlight the negative effect of human rights violations and the importance of statistical data for FDI decisions.

Based on the assumptions of rational choice theory (Friedman, 1953), the decisions of entrepreneurs are based on pure profit-maximisation. Accordingly, the decision to invest in a particular country follows the rationale to reduce costs, secure the supply chain and/or to gain a monopolistic position in the respective business sector (Wright \& Zhu, 2018). Moreover, the mechanisms of global trade in the form of trade barriers, rendering investment more lucrative than trade, and country-specific cost advantages (c.f., Porter, 1998) determine the investment decisions of multinationals. In difference to classical economic thinking, which posits the emergence of a global market equilibrium, trade barriers, differences in relative prices of production factors, transportation costs and spatial distances create room for arbitrage and incentives to relocate parts of the production (Pantselidis \& Nikolopolous, 2008). The OLI paradigm (Dunning, 1979), which reflects these considerations, explains under which circumstances enterprises decide, whether to export, to license or to produce a product abroad. Accordingly, the most important factors are the market size of the host country and the endowment of the host country with resources.

Despite its explanatory power, Dunning's theoretical model does not elucidate where to locate institutional factors in the cost-benefit calculations of investors. Therefore, we discuss the two main factors of our interest and evaluate their impact on FDI attraction: Statistical Capacity, which is essential for good policymaking and for reporting on 
progress, and Human Rights, which is used as a proxy for the moral perception of the target country.

\section{Statistical Capacity}

Statistical capacity has not been used in previous regression models on Foreign Direct Investment and constitutes a rather new variable within the World Bank Development Indicators Database. According to the World Bank (2018), Statistical Capacity refers to a nation's ability to collect, analyse, and disseminate high-quality data about the nation's population and economy and appears to be a strong indicator for state capacity (c.f., Englehart, 2009). Statistical Capacity is not a variable that directly affects investor decisions, but it could appear to be an apt proxy reflecting the amount of available information concerning a country. From the perspective of most economic theories (c.f., Kahneman, Slovic, \& Tversky, 1982), one would assume that investors prefer countries that provide more quality data concerning economically relevant information, such as inflation, literacy rates or economic growth. As a result, a meagre information situation increases the uncertainties associated with an investment and makes it more difficult to conduct a risk assessment.

\section{Human Rights and FDI: Two Different Views}

Based on the assumption of mainly profit-oriented enterprises, human rights violations in the country to be invested in would be irrelevant for decision makers 'ceteris paribus'. An entrepreneur facing the decision, where to invest, would be indifferent, as long as human rights do not have a quantifiable impact on the cost-benefit calculation of the entrepreneur.

\subsection{Reluctance of Multinationals for Human Rights}

While scholarship remains deeply divided over the impact of human rights on FDI, the traditional school and in particular proponents of dependency theory (Lenin, 1977; c.f., Blanton \& Blanton, 2007) posit that multinationals stand to benefit economically from autocratic power structures. According to their argument, countries with higher levels of human rights tend to have better collective bargaining standards and provide socio-economic rights to a greater part of the population. While the existence of unions drives up wages, free and equal access to the market enhances competition, reducing the rents for enterprises. An agreement between a multinational enterprise, which gains exclusive access to a resource or a market, and an authoritarian regime, which is capable of enforcing this monopoly position by outlawing socio-economic rights of third parties, would constitute an ideal type of this arrangement (c.f., Bayulgen, 2010). Historic and contemporary examples of this kind of cooperation including the political economies of Post-Soviet and South American dictatorships (ibid.; Kopper, 2017) have contributed to the dominance of this argument in the public debate.

\subsection{Preference of Multinationals for Human Rights}

However, this view might fall short of capturing the importance of institutional, legal and reputational determinants for attracting foreign capital (Acemoglu \& Robinson, 2012), which are again strongly determined by rule of law standards, which form an integral part of any human rights regime. The codification and enforcement of property rights for instance reduces risks of deliberate expropriation. In addition, individual economic rights enhance the prospects of economic growth and lead to a diversification of the economy, making investment by foreign countries more profitable. The enhancement of property rights and the political changes in East Asia, particularly in South Korea and Taiwan, might be representative of this narrative. In addition, human rights might also cover the dimension of foreign affairs, as trade conflicts might jeopardise the profitability of the investment projects. Previous empirical research backs the argument that US FDI in Africa is connected to foreign policy (Biglaiser \& DeRouen, 2007). Countries violating human rights are more likely to fall under the radar of international sanctions and trade restrictions, which increase the legal risks of enterprises to invest in these countries and drives up the costs of maintaining and enhancing already existing production facilities. The cases of North Korea, Sudan, Iran and the Apartheid era in South Africa are examples of the disruptive effect of foreign relations on trade and commerce (Levy, 1999, c.f., Kim, 2013). In addition, compliance risks concerning social and environmental standards might discourage international enterprises from investing in countries, where human rights violations are widely spread. Recently, legal changes have intensified the pressure to comply with extraterritorial legislation (c.f., UK Modern Slavery and Human Trafficking Act). Human rights violations in the supply chain, which are linked to low institutional quality, might entail a reputational dimension, as well. According to current research (Garriga, 2016), investors seem to reward countries' commitment to human-rights regimes either because of their own reputation or because they can use the host country's reputation to deflect responsibility in front of the global society.

\subsection{Empirical Evidence}

Empirically, the relevance of human rights as locational factors for FDI—whether direct or indirect—has been 
supported by research, most notably by Campos and Kinoshita (2003), Blanton and Blanton (2007) and Garriga et al. (2016). Some studies however provided a mixed picture. Blanton and Blanton (2009) found that the effect of the human rights situation in the host country on FDI inflows depends on the industrial sector. While FDI in branches that require a high standard of human capital are encouraged by better human rights conditions and even better labour standards (Blanton \& Blanton, 2012), resource oriented FDI is not repelled by human rights violations and might even contribute to a deterioration of human rights conditions (see also: Vadlamannati \& Coorey, 2015).

Based on these general considerations, we tested the following hypotheses, which refer to statistical capacity and the political system:

Hypothesis 1: A better information environment, expressed in a higher score of the statistical capacity, corresponds with a higher level of FDI.

Hypothesis 2: Due to high reputational and legal risks, countries violating human rights receive less FDI than other countries.

\section{The Model and the Data}

\subsection{Dependent Variable}

The dependent variable of our model is Foreign Direct Investment. In differing from portfolio investment, FDI refers to the long-term interest of companies to develop a long-lasting presence in the market. In order to measure FDI, we rely on stock data provided by the UNCTAD. The preference of stock data over FDI flow data has two methodological reasons. FDI stock data does seldomly include negative values and is more stable over time (c.f., Lipsey, 2007; Wacker, 2013). Moreover, strong fluctuations of FDI flow data typically occur in oil exporting countries and might produce statistical noise. In fact, the annual changes within FDI flows appear to reflect the vicissitudes of the international oil price and other external effects, which we cannot control within our model.

\subsection{Independent Variables}

Tracing the influence of Human Rights and Statistical Capacity on the performance of FDI stocks requires controlling for variables, which determine foreign direct investment. The control variables include population, GDP per capita, natural resource endowment, inflation, taxes and trade openness. The variable population represents the size of the market, which is, according to Dunning, one of the main reasons to relocate the production abroad. Prior research has demonstrated the importance of the market size for FDI in Africa (Asiedu, 2006; Chen et al., 2015, Mateev, 2009). Likewise, GDP per capita has been used in previous models as a variable for describing the development level of the specific country (c.f., Asiedu, 2006; Blanton \& Blanton, 2007). Following the model of Dunning, investors might be more likely to invest in developed economies, due to a higher level of social development and infrastructure. Moreover, other concepts of development indicators are closely tied to GDP per capita, which, for example, forms an integral part of the human development index, and human capital. As investment might be connected to trade, we included a variable for measuring trade openness, which measures the integration of a country in the global economy and has been included in earlier research on FDI (c.f., Edwards 1990, Hausmann \& Fernandez-Arias, 2000; Anyanwu, 2012). Natural resources appear to be an important locational factor, explaining investment in resource seeking industries (Mohamed \& Sidiropoulos, 2010; Anyanwu, 2012). At the same time, natural resources might distort the correlation between FDI and human rights, as resources have a negative impact on democracy and human rights (c.f., Venables, 2016), but a positive influence on the attraction of specific forms of FDI (Blanton \& Blanton, 2009). Therefore, past research on FDI has used natural resources revenues as part of GDP for illustrating the effect of resources on FDI inflows or stock data (Blanton \& Blanton, 2007; Bopkin, Mensah, \& Asamoah, 2015). Given the poor data situation in many economies in Sub-Saharan Africa, we were unable to include further variables discussed in literature concerning FDI such as indices measuring institutional competitiveness (c.f., World Economic Forum Global Competitiveness Index) or literacy rates. Integrating these variables would increase the number of missing data and accordingly reduce the number of countries in the data set (c.f., Büthe \& Milner, 2008).

The explanatory variables refer to our two hypotheses. In order to measure the quality of institutions, we used the Statistical Capacity figures of the World Bank (2019). We regard this number as an indicator for data availability on the respective economy, as it reflects the quantity of information concerning the country disseminated by official institutions.

For measuring human rights, we created a dummy variable for human rights, based on the free/not-free classification of the Freedom House Index (c.f., Adam \& Filippaios, 2007; Büthe \& Milner, 2008). We focused here on the civil liberties score, as it includes organisational rights, rule of law as well as individual rights and as it examines "elements of economic liberalisation" (Kono, 2008). The integration of economic rights and legal 
stability is important, to control for the legal system of the host countries (compare Porter 1990). Finally, we classified countries with a civil liberties score of seven as the worst performers of human rights. The idea of clearly distinguishing between the most repressive regimes and mixed types is based on the following reasoning:

Given the difficulties in obtaining reliable information concerning the human rights situation in the host countries, Western companies might face difficulties when anticipating the minor differences among political regimes within Sub-Saharan Africa. Notorious violators of human rights, which repress civil liberties and individual rights, are more exposed to public scrutiny than other regimes. Moreover, we observe an ongoing methodological controversy over classification of political regimes (Gastil, 1990; Veenendaal, 2015). The controversy applies to countries, which have elements of democracies and elements of authoritarian regimes (c.f., Treisman, 2011). To avoid these problems, we focused on countries with an extremely low level of human rights, as the classification of these regimes is less dependent on a specific methodology.

\subsection{Reverse Causality}

Considering the variables used in the hard and soft determinants set, we also dealt with the issue of reverse causality. In the case of reverse causality, it is difficult to distinguish between cause and effect. A higher level of GDP per capita (Blanton \& Blanton, 2007; Garriga, 2016), might influence the level of FDI stock, while GDP per capita might be influenced by a higher level of FDI stock (c.f., Pham, 2003). A similar logic might also apply to the linkage between political factors and GDP per capita. Moreover, previous research (c.f., Qureshi \& Ahmed, 2012) has illustrated the "inter-linkage" between the political system with GDP per capita and the strong role of both factors on FDI attraction. In the following models, we have considered these potential relationships and controlled for serial multicollinearity.

\section{Empirical Results}

\subsection{Models}

For analysing the effect of Statistical Capacity and Human Rights on FDI in Sub-Saharan Africa, we applied a panel data analysis because of the nature of our data which consist of multiple countries over a ten-year time period (Hsiao, 2014; Stock \& Watson, 2015) Panel data analysis has several advantages such as a large number of observations. Moreover, it increases the degree of freedom, reduces the collinearity among the explanatory variables and provides a more complex analysis that cannot be addressed using cross sectional or time series data analysis.

In the study, the data of $\boldsymbol{i}=\mathbf{4 1}$ countries (see Annex) combined with $\boldsymbol{t}=\mathbf{1 0}$ years (2006-2015), would provide a total of in 410 observations. However, we missed some values due to incomplete data from the World Bank database. This applies not only to specific variables such as openness, inflation and taxes, but also to specific countries such as Eritrea, Somalia, South Sudan and Sudan, which could not be integrated in our regression model from the beginning. We will therefore discuss the implications of our findings given the absence of these countries in our data set.

Our base line model is as follows:

$$
F D I_{i t}=\beta_{i}+\beta_{1} G D P p C_{i t}+\beta_{2} \text { Pop }_{i t}+\beta_{3} \text { Infl }_{i t}+\beta_{4} \text { Open }_{i t}+\beta_{5} \text { Res }_{i t}+\beta_{6} \text { Tax }_{i t}+\beta_{7} \text { Stat }_{i t}+\beta_{8} H R_{i t}+\varepsilon_{i t}
$$

In the model, index $\boldsymbol{i}$ denotes the country and, $\boldsymbol{t}$ denotes the year of the observation. Accordingly, $\varepsilon_{i t}$ is the error variable, which varies over country and year. The variable $\left(F D I_{i t}\right)$ refers to the logged of FDI stock of a country in a given year $t$. The key set of the explanatory variables are statistical capacity (Stat) and human rights $(H R)$. As control variables, we included the logged value of GDP per capita (GDPpc), the logged value of the total population in millions (Pop), the level of trade openness (Open), the inflation rate (Infl), the share of resources in a country's GDP (Res) and the total tax rates (Tax). The log transformations of the macroeconomic variables (FDI, GDP per capita and population) have the purpose to stabilise variance and to prevent that extreme values influence the findings of the model (Blanton \& Blanton, 2007; Biglaiser \& Rouen, 2008).

We evaluated our model through panel data techniques by applying pooled Ordinary Least Square (OLS) regression, panel model with random effects and dynamic panel estimators in gretl.

The first model is the pooled OLS regression model, which is also our baseline model. The outcome of the pooled OLS used 389 observations from 2006 to 2015. Despite the inherent limitations of OLS regressions concerning the interpretation of panel data, the pooled OLS estimator employed in this paper was the starting point of our statistical analysis. In the pooled OLS regression, important factors that are relevant to a given country are left out in the estimates. This means that each country in the data is treated without respect of potential country dependent effects (Asterious \& Hall, 2006). However, the integration of country and time specific effects is essential to 
account for geographical, political and institutional factors which do not change over time. Therefore, the heterogeneity of the individual country which is not captured by the observed explanatory variables can influence the results of our estimation (Hsiao, 2014). Hence, the pooled OLS model alone would be an inappropriate method for our panel data analysis study.

To eliminate the problem of heterogeneity, we used a Random Effect model. The random effect estimator allows us to account for individual heterogeneity as it treats the constants for each section as a random parameter. It reduces potential biases caused by country specific effects even with datasets that have some missing values.

We assumed here the individual-country effect to be random and uncorrelated with the explanatory variables. This means that we handle the constants for each individual country as random and not as fixed parameters (Greene, 2012). Accordingly, the intercept of each country $\beta_{i}$ consists of a fixed part $\beta_{0}$ and a random individual difference $u_{i}$ :

$$
\beta_{i}=\beta_{0}+u_{i}
$$

We assume that $u_{i}$ has a zero mean standard random variable (Asterious \& Hall, 2006). If we substitute the $\beta_{i}$ with the new definition, we come to the following equation (for the following equation applies $w_{i t}=u_{i}+e_{i}$ ):

$$
F D I_{i t}=\beta_{0}+\beta_{1} G D P p C_{i t}+\beta_{2} \text { Pop }_{i t}+\beta_{3} \text { Infl }_{i t}+\beta_{4} \text { Open }_{i t}+\beta_{5} \operatorname{Res}_{i t}+\beta_{6} \text { Tax }_{i t}+\beta_{7} \text { Stat }_{i t}+\beta_{8} H R_{i t}+w_{i t}(3)
$$

The equation is estimated using a robust standard error random effect model which resulted in the use of 389 observation from 2006-2015.

In the dynamic panel model, we extended the model, by including a lag form of the dependant variable (FDI) as an additional explanatory variable. We included the lagged variable for FDI, because FDI might be attracted by past FDI decisions. As a result, we re-examined our model by including the past stock values of FDI to the explanatory variables and estimated the dynamic panel data using the Generalised Method of Moments (GMM) as proposed by Arellano and Bover (1995) and Blundell-Bond (1998). This transformation leads to the following equation:

$$
F D I_{i t}=\alpha F D I_{t-1}+\beta_{0}+\beta_{1} G D P p C_{i t}+\beta_{2} \text { Pop }_{i t}+\beta_{3} \operatorname{Infl}_{i t}+\beta_{4} \text { Open }_{i t}+\beta_{5} \text { Res }_{i t}+\beta_{6} \text { Tax }_{i t}+\beta_{7} \text { Stat }_{i t}+\beta_{8} H R_{i t}+\left(w_{i t}\right) \text { (4) }
$$

The equation is estimated using a one-step system-GMM method which is asymptotically robust to general heteroscedasticity and corrected for biases. The dynamic sys-GMM outcome used 353 observations of 41 Sub-Saharan economies from 2006-2015.

Table 1. Overview of variables

\begin{tabular}{lll}
\hline & Name & Source \\
\hline FDI & Foreign Direct Investment (Stock) & UNCTAD \\
GDPpC & GDP per capita & World Bank \\
Pop & Population & World Bank \\
Infl & Inflation Rate & World Bank \\
Open & Trade Openness & World Bank \\
Res & Resources (as Part of GDP) & Work Bank \\
Tax & Tax rate & World Bank \\
Stat & Statistical Capacity & World Bank \\
HR & Human Rights Violations & Based on Freedom House \\
\hline
\end{tabular}

\subsection{Findings}

Based on the above analysis, we concluded that the dynamic system model and the Random effect model are preferred to the OLS. However, for completeness, we nevertheless reported the regression results of all three models. These results are reported in Table 2. The results are robust to the use of heteroskedastic consistent and autocorrelation-consistent standard errors. 
Table 2. Result table

\begin{tabular}{llll}
\hline & $O L S$ & $R E$ & Dynamic \\
\hline 1_FDI_St(-1) & & & $0.0881087^{* *}$ \\
const & -2.12428 & -1.35526 & -0.299483 \\
1_GDPpC & $0.855074^{* * *}$ & $0.939677^{* * *}$ & $0.750174^{* * *}$ \\
1_Pop & $0.983908^{* * *}$ & $0.932218^{* * *}$ & $0.848153^{* * *}$ \\
Open & $1.83456^{* * *}$ & $1.07110^{* * *}$ & $1.34438^{* * *}$ \\
Res & 0.628131 & 0.861094 & 0.243546 \\
Tax & 0.0156995 & -0.123209 & -0.0265995 \\
Stat & $2.51593^{* *}$ & $1.81901^{*}$ & $2.00354^{* * *}$ \\
Infl & -1.79742 & $-1.48342^{* *}$ & $-2.49265^{* * *}$ \\
HR & $-1.05738^{*}$ & $-0.527514^{* * *}$ & $-0.999798^{* * *}$ \\
\hline
\end{tabular}

The results show that GDP, population and trade openness share a positive coefficient and are significant in all three models. High GDP, population, growth and trade openness captures the purchasing power, market size and a country's integration in the global economy, as trade openness reflects the weight of exports and imports in the GDP of the observed economy. These patterns of FDI would be predicted by Dunning's eclectic OLI paradigm, according to which firms look for market opportunities when making investment decisions abroad.

In addition, we find out that statistical capacity exerts a positive and significant influence on FDI in all three models. This implies that the quality of statistical information concerning the host country seemingly attracts FDI stock. In contrast, human rights violations seem to deter foreign investors, if they pass a certain threshold, which we defined as a score of seven in the civil liberties rating of Freedom House.

The coefficient of inflation is negative and significant as we expected. High inflation rates increase uncertainty and discourages long term investment (Romer, 2019). Furthermore, our dummy variable for human rights is significant in our models, which implies that investors avoid countries with a low score in human rights.

Some of our findings are not in line with previous research, though:

In contrast to previous studies (Devereux \& Freeman, 1995; Fuest et al., 2005; OECD, 2008), the results show that taxes do not exert a significant effect on FDI Sub-Saharan Africa. This might be driven by the fact that foreign invested enterprises are often subject to tax incentives or invest in free trade areas with a different taxation scheme than in the entire economy (compare: Blumström \& Kokko, 2003).

The same applies to resources. According to our findings, resources are not determining FDI decisions in Sub-Saharan Africa, what differs from earlier research (c.f., Blanton \& Blanton, 2007). We argue that this finding reflects the paradigm shift in Sub-Saharan Africa's service market, which has been observed by the United States International Trade Commission (Powell, 2017).

\section{Discussion}

The empirical analysis supports the traditional assumption that the size of the host market and the development level of the economy, expressed in terms of GDP per capita, mainly determine FDI. Trade openness is also conducive for FDI attraction, what indicates that FDI does not substitute trade flows.

Moreover, we could prove that soft variables play a significant role in determining the level of FDI stocks in Sub-Saharan Africa. The significance of statistical capacity and its positive effect on foreign direct investment is a sign that international investors require transparency of data to avoid economic uncertainties. In this sense, the lack of data suggests deficits in the information collection processes or intended political disclosure. Moreover, statistics are essential for all stages of evidence-based decision-making from the perspective of the state to improving socio-economic policies, but also for international companies, which consider investment decisions in the region.

At the same time, we could confirm that human rights constitute a relevant criterion for investment decisions. The reluctance to invest in countries with extremely low levels of human rights might be attributed to the vicious cycle of resource abundance, human rights violations, internal conflicts and as well as the local political economy, which determines the degree of FDI liberalisation (c.f., Bayulgen, 2010). This might apply to the situation in the Central African Republic and Equatorial Guinea, which belong to the worst regional performers in terms of human rights, and which are characterised by a strong dependency on resources (c.f., McSherry, 2006; Souleymane, 2018). Reputational effects might play an additional role in deterring investments in these regions, as highlighted by earlier research (Garriga, 2016). 
The situation in countries such as Eritrea, South Sudan, Sudan and Somalia, which were not included in the model due to lack of data, might even strengthen our argument. The stated economies share a weak reputation, provide little data about economic figures and attract only a few foreign investors.

\section{Conclusion}

Our findings confirm the theoretical claim that uncertainties exert a negative influence on FDI attraction. Uncertainties can be caused by political factors such as the occurrence of human rights violations or by the deficits of a nation in providing data about its economic structure. Based on the calibration of the variable for human rights, which centres on the worst performers in terms of human rights and democracy, we conclude that investors rather avoid countries with human rights violations. The integration of Statistical Capacity, as a measurement instrument for the uncertainties faced by investors, constitutes a novel approach and might also be considered in the case of other regions, which do not provide data on socio-economic factors. The positive relationship between FDI and statistical capacity reflects here the relevance of data, which influences FDI decisions and which will continue to gain relevance in future.

Nevertheless, the results provided by our contribution need to be supplemented by additional research on the linkage between FDI, human rights and political regimes. Although we could verify the claim that institutions explain the differences among African countries, we need to deepen our knowledge on different forms of FDI in terms of business sector and company structure as well as the role of different countries of origin. The differences between investment from Western and developing countries for example the BRICS concerning FDI determinants are highly relevant, as demonstrated by previous research (c.f., Morgan, 2019). Another aspect for future research on the general relationship between FDI and more general institutional factors could be the integration of the WEF (World Economic Forum) Global Competitiveness index for the institutional competitiveness of the countries, given that the database includes a sufficient number of Sub-Sahara economies.

Quantitative research alone might be unable to fill this gap, as it is incapable of analysing the worst performers of FDI. A case study focusing on the political economy of FDI would therefore be valuable to trace all parts of the linkage between FDI and political factors. Shedding the light to the worst performers of FDI attraction Eritrea, Somalia and Sudan could be helpful for unearthing the preferences of the few FDI investors in this region. 


\section{Appendix A. List of Countries}

\begin{tabular}{l}
\hline List of Countries \\
\hline Angola \\
Benin \\
Botswana \\
Burkina Faso \\
Burundi \\
Cabo Verde \\
Cameroon \\
Central African Republic \\
Chad \\
Comoros \\
Congo. Dem. Rep. \\
Congo. Rep. \\
Cote d'Ivoire \\
Equatorial Guinea \\
Eswatini \\
Ethiopia \\
Gabon \\
Gambia. The \\
Ghana \\
Guinea-Bissau \\
Kenya \\
Lesotho \\
Liberia \\
Madagascar \\
Malawi \\
Mali \\
Mauritania \\
Mauritius \\
Namibia \\
Niger \\
Nigeria \\
Rwanda \\
Senegal \\
Seychelles \\
Sierra Leone \\
South Africa \\
Tanzania \\
Togo \\
Uganda \\
Zambia \\
Zimbabwe \\
\hline
\end{tabular}

\section{References}

Acemoglu, D., \& Robinson, J. A. (2012). Why Nations Fail: The Origins of Power, Prosperity, and Poverty. ASEAN Economic Bulletin, 29(2). https://doi.org/10.1355/ae29-2j

Adam, A., \& Filippaios, F. (2007). Foreign direct investment and civil liberties: A new perspective. European Journal of Political Economy, 23(4), 1038-1052. https://doi.org/10.1016/j.ejpoleco.2006.08.006

Anyanwu, J. (2012). Why Does Foreign Direct Investment Go Where It Goes? New Evidence from African Countries. Annals of Economics and Finance, 13(2), 425-462.

Anyanwu, J., \& Erhijakpor, A. (2004). Trends and Determinants of Foreign Direct Investment in Africa.

Arellano, M., \& Bover, O. (1995). Another Look at the Instrumental Variable Estimation of Error-Component Models. Journal of Econometrics, 68, 29-52. https://doi.org/10.1016/0304-4076(94)01642-D

Asiedu, E. (2006). The Role of Natural Resources, Market Size, Government Policy, Institutions and Political Instability. The World Economy, 29(1), 63-77. https://doi.org/10.1111/j.1467-9701.2006.00758.x 
Asteriou, D., \& Hall, S. G. (2007). Applied econometrics: A modern approach using EViews and Microfit. Basingstoke: Palgrave Macmillan.

Bayulgen, O. (2010). Foreign Investment and Political Regimes (The Oil Sector in Azerbaijan, Russia, and Norway). Cambridge: Cambridge University Press. https://doi.org/10.1017/CBO9780511676048

Bevan, A. A., \& Danbolt, J. (2004). Testing for inconsistencies in the estimation of UK capital structure determinants. Applied Financial Economics, 14(1), 55-66. https://doi.org/10.1080/0960310042000164220

Biglaiser, G., \& DeRouen, K. (2007). Following the Flag: Troop Deployment and U.S. Foreign Direct Investment. International Studies Quarterly, 51(4), 835-854. https://doi.org/10.1111/j.1468-2478.2007.00479.x

Blanton, R., \& Blanton, S. (2012). Rights, Institutions, and Foreign Direct Investment: An Empirical Assessment. Foreign Policy Analysis, 8(4), 431-451. https://doi.org/10.1111/j.1743-8594.2011.00161.x

Blanton, S., \& Blanton, G. (2007). What Attracts Foreign Investors? An Examination of Human Rights and Foreign Direct Investment. Journal of Politics, 69(1). https://doi.org/10.1111/j.1468-2508.2007.00500.x

Blanton, S., \& Blanton, R. (2009). A Secoral Analysis of Human Rights and FDI: Does Industry Type Matter? International Studies Quarterly, 53(2), 469-493. https://doi.org/10.1111/j.1468-2478.2009.00542.x

Blomstrom, M., \& Kokko, A. (2003). The Economics of Foreign Direct Investment Incentives. CEPR Discussion Paper No. 3775. https://doi.org/10.3386/w9489

Blundell, R., \& Bond, S. (1998). Initial conditions and moment restrictions in dynamic panel data models. Journal of Econometrics, 87(1), 115-143. https://doi.org/10.1016/S0304-4076(98)00009-8

Bopkin, G., Mensah, L., \&Asamoah, M. (2015). Foreign direct investment and natural resources in Africa. Journal of Economic Studies, 42(4), 608-621. https://doi.org/10.1108/JES-01-2014-0023

Büthe, T., \& Milner, H. V. (2008). The politics of foreign direct investment into developing countries: Increasing FDI through international trade agreements? American Journal of Political Science, 52(4), 741-762. https://doi.org/10.1111/j.1540-5907.2008.00340.x

Campos, N. F., \& Kinoshita, Y. (2003). Why does FDI go where it does? New evidence from the transition economies. IMF Working paper No. 223, International Monetary Fund, Washington. https://doi.org/10.2139/ssrn.414540

Carter, D. B., Wellhausen, R. L., \& Huth, P. K. (2019). International Law, Territorial Disputes, and Foreign Direct Investment. International Studies Quarterly, 63(1), 58-71. https://doi.org/10.1093/isq/sqy046

Coorey, A., Tamazian, A., \&Vadlamnati, K. (2015). What Drives FDI Policy Liberalization? An Empirical Investigation. Regional Science and Urban Economics, 49, 179-189. https://doi.org/10.1016/j.regsciurbeco.2014.06.008

de Bakker, F. G., \& den Hond, F. (2011). A Disputed Contract: IHC Caland in Burma. In W. Dubbink, L. van Liedekerke \& H. van Luijk (Eds.), European Business Ethics Casebook (Issues in Business Ethics, vol. 29). Springer, Dordrecht. https://doi.org/10.1007/978-90-481-9334-9_13

De Mello, L. R. (1999). Foreign direct investment-led growth: Evidence from time series and panel data. Oxford Economic Papers, no. 51. https://doi.org/10.1093/oep/51.1.133

Dellis, K., Sondermann, D., \& Vansteenkiste, I. (2017). Determinants of FDI inflows in advanced economies: Does the quality of economic structures matter? Working Paper Series 2066, European Central Bank.

Devereux, M. P., \& Freeman, H. (1995). The Impact of Tax on Foreign Direct Investment: Empirical Evidence and the Implications for Tax Integration Schemes. International Tax and Public Finance, 2, 85-106. https://doi.org/10.1007/BF00873108

Edwards, S. (1990). Capital Flows, Foreign Direct Investment, and Dept-Equity Swaps in Developing Countries. Working Paper No. 3497 NBER. https://doi.org/10.3386/w3497

Englehart, N. A. (2009). State Capacity, State Failure, and Human Rights. Journal of Peace Research, 46(2), $163-$ 180. https://doi.org/10.1177/0022343308100713

Fernandez-Arias, E. (2011). The New Wave of Capital Inflows: Sea Change or Just Another Tide? IDB Publications (Working Papers) 1317, Inter-American Development Bank.

Freedom House. (2020). Freedom in the World 2020 Methodology. Retrieved from https://freedomhouse.org/reports/freedom-world/freedom-world-research-methodology 
Friedman, M. (1953). Essays in Positive Economics. Chicago: University of Chicago Press.

Fuest, C., Huber, B., \& Mintz, J. (2005). Capital Mobility and Tax Competition. Foundations and Trends in Microeconomics, 1(1), 1-62. https://doi.org/10.1561/0700000001

Garriga, A. (2016). Human Rights Regimes, Reputation, and Foreign Direct Investment. International Studies Quarterly, 60(1), 160-172. https://doi.org/10.1093/isq/sqw006

Gastil, R. D. (1990). The Comparative Survey of Freedom: Experiences and Suggestions. Studies in Comparative International Development, 25(1), 25-50. https://doi.org/10.1007/BF02716904

Greene, W. H. (2012). Econometric Analysis. London: Pearson.

Guardian. (2016). Children as young as seven mining cobalt used in smartphones, says Amnesty. Retrieved from https://www.theguardian.com/global-development/2016/jan/19/children-as-young-as-seven-mining-cobalt-f or-use-in-smartphones-says-amnesty

Hoang, T., Wiboonchutikula, P., \& Tubtimtong, B. (2010). Does Foreign Direct Investment Promote Economic Growth in Vietnam? ASEAN Economic Bulletin, 27(3), 295-311. https://doi.org/10.1355/ae27-3d

Hsiao, C. (2014) Analysis of Panel Data. Cambridge: Cambridge University Press. https://doi.org/10.1017/CBO9781139839327

Kahneman, D., Slovic, P., \& Tversky, A. (1982). Judgment under uncertainty: Heuristics and biases. Cambridge: Cambridge University Press. https://doi.org/10.1017/CBO9780511809477

Kim, D. H. (2013). Coercive Assets? Foreign Direct Investment and the Use of Economic Sanctions. International Interactions, 39(1), 99-117, https://doi.org/10.1080/03050629.2013.751305

Klein, M., Aaron, C., \& Hadjimichael, B. (2001). Foreign Direct Investment and Poverty Reduction. Policy Research Working Paper 2613, World Bank. https://doi.org/10.1596/1813-9450-2613

Kono, D. (2008). Democracy and Trade Discrimination. Journal of Politics, 70(4), 942-955. https://doi.org/10.1017/S0022381608080985

Kopper, C. (2017). VW do Brasil in der brasilianischen Militärdiktatur 1964-1985. Eine historische Studie.

Kriebitz, A., \& Max, R. (2020). The Xinjiang Case and Its Implications from a Business Ethics Perspective. Human Rights Review. https://doi.org/10.1007/s12142-020-00591-0.

Lenin, V. (1977). Imperialism: The Highest Stage of Capitalism. New York: International Publishers.

Levy, P. I. (1999). Sanctions on South Africa: What Did They Do. Working Papers 796, Economic Growth Center, Yale University. https://doi.org/10.1257/aer.89.2.415

Lipsey, R. E. (2007). Defining and measuring the location of FDI output. Working Paper 12996, NBER, Cambridge, MA. https://doi.org/10.3386/w12996

Mateev, M. (2009). Determinants of Foreign Direct Investment in Central and Southeastern Europe: New Empirical Tests. Oxford Journal, 8(1), 133-149.

McSherry, B. (2006). The Political Economy of Oil in Equatorial Guinea. African Studies Quarterly, 8(3), 23-45.

Mohamed, S. E., \& Sidiropoulos, M. G. (2010). Another look at the Determinants of Foreign Direct Investment in MENA Countries: An Empirical Investigation. Journal of Economic Development, 35(2). https://doi.org/10.35866/caujed.2010.35.2.005

Morgan, P., \& Yu, Z. (2019). Tracing the Legacy: China's Historical Aid and Contemporary Investment in Africa. International Studies Quarterly, 63(3), 558-573, https://doi.org/10.1093/isq/sqz021

Naughton, B., \& Lardy, N. (1996). China's emergence and prospects as a trading nation. Brookings papers on economic activity. https://doi.org/10.2307/2534623

OECD. (2008). Tax Effects on Foreign Direct Investment - Recent Evidence and Policy Analysis. OECD Tax Policy Studies No. 17.

Ogunniyi, M. B., \& Igberi, C. O. (2014). The impact of foreign direct investment on poverty reduction in Nigeria. Journal of Economics and Sustainable Development, 5(14).

Pantelidis, P., \& Nikolopoulos, E. (2008). FDI Attractiveness in Greece, International Advances in Economic

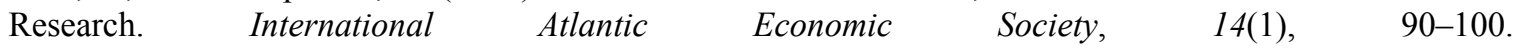
https://doi.org/10.1007/s11294-007-9106-y 
Pham, H. (2003), The Economic Impact of Foreign Direct Investment Flows on Vietnam: 1988-1998. Asian Studies Review, 2791, 81-98. https://doi.org/10.1080/10357820308713367

Porter, M. E. (1998). The Competitive Advantage of Nations. London: Palgrave Macmillan UK. https://doi.org/10.1007/978-1-349-14865-3

Powell, J. (2017). The Sub-Saharan African Services Economy: Insights and Trends. United States International Trade Commission. Working Paper ID-046.

Qureshi, M. G., \& Ahmed, E. (2012). The Inter-linkages between Democracy and Per Capita GDP Growth: A Cross Country Analysis. PIDE-Working Papers, 85, Pakistan Institute of Development Economics.

Romer, D. (2019). Advanced Macroeconomics (5th ed.). New York: McGraw Hill.

Singh, H., \& Jun, K. W. (1995). Some New Evidence on Determinants of Foreign Direct Investment in Developing Countries. World Bank Policy Research Working Paper 1531.

Smith, S. (1997). Restrictive Policy toward Multinationals: Argentina and Korea. Case Studies in Economic Development, 2, 178-189.

Souleymane, C. et al. (2018). Central Africa Country Report. Breaking the Cycle of Conflict and Instability. World Bank Working Paper 127056.

Stock, J. H., \& Watson, M. M. (2019). Introduction to Econometrics. London: Pearson.

Treisman, D. (2011). The Return: Russia's Journey from Gorbachev to Medvedev. New York: Free Press.

Vadlamannati, K. C., \& Cooray, A. V. (2015). What Drives FDI Policy Liberalization? An Empirical Investigation. Regional Science and Urban Economics, 49, 179-189. https://doi.org/10.1016/j.regsciurbeco.2014.06.008

Veenendaal, W. P. (2015). Democracy in microstates: why smallness does not produce a democratic political system. Democratization, 22(1), 92-112. https://doi.org/10.1080/13510347.2013.820710

Venables, A. J. (2016). Using Natural Resources for Development: Why Has It Proven So Difficult? Journal of Economic Perspectives, 30(1), 161-184. https://doi.org/10.1257/jep.30.1.161

Wacker, K. M. (2013). On the Measurement of Foreign Direct Investment and Its Relationship to Activities of Multinational Corporations. Working Paper Series 1614. European Central Bank.

Wei, S. (2000). How Taxing is Corruption on International Investors? The Review of Economics and Statistics, 82(1), 1-11. https://doi.org/10.1162/003465300558533

Wright, J., \& Zhu, B. (2018). Monopoly Rents and Foreign Direct Investment in Fixed Assets. International Studies Quarterly, 62(2), 341-356. https://doi.org/10.1093/isq/sqy010

\section{Copyrights}

Copyright for this article is retained by the author, with first publication rights granted to the journal.

This is an open-access article distributed under the terms and conditions of the Creative Commons Attribution license (http://creativecommons.org/licenses/by/4.0/). 